San Jose State University

SJSU ScholarWorks

Master's Theses

Master's Theses and Graduate Research

1993

\title{
Effect of extrusion temperature on the color and functional properties of full fat pinto bean flour
}

Arvind Bansal

San Jose State University

Follow this and additional works at: https://scholarworks.sjsu.edu/etd_theses

\section{Recommended Citation}

Bansal, Arvind, "Effect of extrusion temperature on the color and functional properties of full fat pinto bean flour" (1993). Master's Theses. 669.

DOI: https://doi.org/10.31979/etd.tzfr-vd25

https://scholarworks.sjsu.edu/etd_theses/669

This Thesis is brought to you for free and open access by the Master's Theses and Graduate Research at SJSU ScholarWorks. It has been accepted for inclusion in Master's Theses by an authorized administrator of SJSU ScholarWorks. For more information, please contact scholarworks@sjsu.edu. 


\section{INFORMATION TO USERS}

This manuscript has been reproduced from the microfilm master. UMI films the text directly from the original or copy submitted. Thus, some thesis and dissertation copies are in typewriter face, while others may be from any type of computer printer.

The quality of this reproduction is dependent upon the quality of the copy submitted. Broken or indistinct print, colored or poor quality illustrations and photographs, print bleedthrough, substandard margins, and improper alignment can adversely affect reproduction.

In the unlikely event that the author did not send UMI a complete manuscript and there are missing pages, these will be noted. Also, if unauthorized copyright material had to be removed, a note will indicate the deletion.

Oversize materials (e.g., maps, drawings, charts) are reproduced by sectioning the original, beginning at the upper left-hand corner and continuing from left to right in equal sections with small overlaps. Each original is also photographed in one exposure and is included in reduced form at the back of the book.

Photographs included in the original manuscript have been reproduced xerographically in this copy. Higher quality $6 " \times$ " 9 " black and white photographic prints are available for any photographs or illustrations appearing in this copy for an additional charge. Contact UMI directly to order.

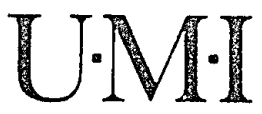



Order Number 1956452

Effect of extrusion temperature on the color and functional properties of full fat pinto bean flour

\author{
Bansal, Arvind, M.S.
}

San Jose State University, 1993

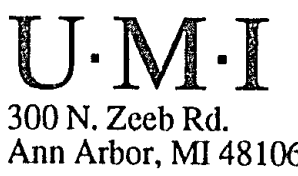





\title{
EFFECT OF EXTRUSION TEMPERATURE ON THE COLOR AND FUNCTIONAL PROPERTIES OF FULL FAT PINTO BEAN FLOUR
}

\author{
A Thesis \\ Presented to \\ The Faculty of the Department of \\ Nutrition and Food science \\ San Jose State University
}

In Partial Fulfillment

of the Requirements for the Degree

Master of Science

in Nutritional science

By

Arvind Bansal

December, 1993 


\section{(C) 1993}

Arvind Bansal

ALL RIGHTS RESERVED 
APPROVED FOR THE DEPARTMENT OF NUTRITION AND FOOD SCIENCE

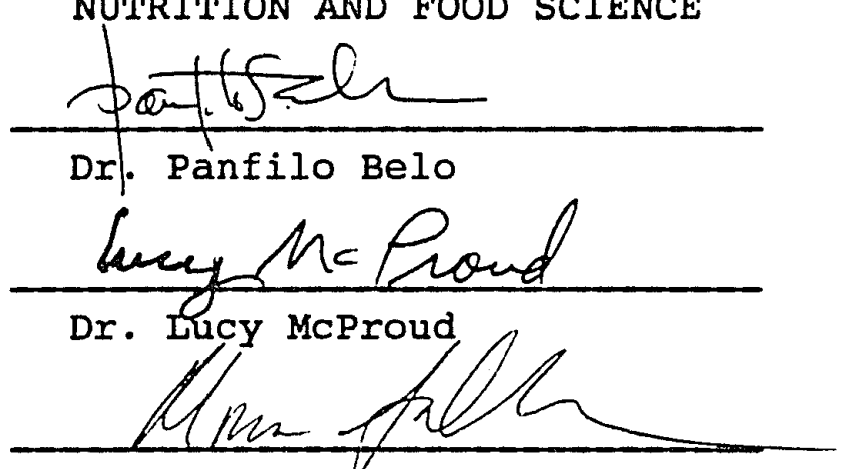

Dr. Miriam saltmarch

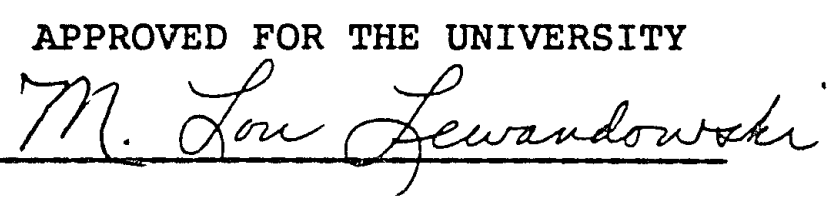




\begin{abstract}
EFFECT OF EXTRUSION TEMPERATURE ON THE COLOR AND FUNCTIONAL PROPERTIES OF FUIL FAT PINTO BEAN FLOUR

by Arvind Bansal
\end{abstract}

Full fat flour prepared from whole pinto beans was extruded in a single screw extruder in the form of a dough with $40 \%$ moisture. Extrusion was performed at 80,100 and $120^{\circ} \mathrm{C}$. Extrudates were dried at $45^{\circ} \mathrm{C}$, and ground to pass through a 40 mesh seive. The resulting products were analysed for proximate composition, color and functional properties and compared against the unextruded full fat pinto bean flour (Control). Nitrogen solubility (NS), water absorption capacity (WAC), and emulsification capacity (EC) were determined at various $\mathrm{pH}$ levels. No significant difference was observed in the protein content of the unextruded (control) and the extruded pinto bean flour. While the control showed a typical NS-pH profile for plant proteins, extrusion at various temperatures lowered the NS at all $\mathrm{pH}$ levels, except at $120^{\circ} \mathrm{C}$. WAC decreased as the extrusion temperature was increased at all $\mathrm{pH}$ levels. The EC increased at $80^{\circ} \mathrm{C}$ and decreased thereafter at 100 and $120^{\circ} \mathrm{C}$ at all pH levels, except $\mathrm{pH}$ 10.0. The flour got darker at $120^{\circ} \mathrm{C}$ than at 80 and $100^{\circ} \mathrm{C}$ compared to the control, as shown by the data from Hunter color values. 


\section{ACKNOWLEDGEMENTS}

The author gratefully acknowledges: Dr. Panfilo Belo, my graduate advisor, for his time and technical advice through all phases of this research work. I thank Dr. Miriam Saltmarch and Dr. Lucy McProud for their valuable suggestions in completing this research work and organizing the manuscript. A special thanks to Dr. Elveda Snith for reviewing the initial drafts of this thesis. Last but not the least, I would like to thank Ms. Judith Schallberger for her timely help in the laboratory. 


\section{PREFACE}

This thesis is written in a publication style. The second chapter is written in journal style format in accordance with the January 1992 guidelines of the American Chemical Society and will be submitted to the Journal of Agricultural and Food Chemistry. Chapters 1 and 3 are written according to the guidelines outlined in the Publication Manual of the American Psychological Association, 3rd. edition, 1989. 
Table of contents

Page

List of Tables....................... ix

List of Figures....................... $x$ CHAPTER

1 INTRODUCTION AND REVIEW OF LITERATURE......... 1

Introduction...................... 1

objectives..................... 4

significance of the study............ 4

Review of Literature.................. 6

Pinto Beans..................... 6

Composition................ 6

Proteins................. 8

Functionality of Proteins............ 10

solubility................ 11

Water Absorption............. 13

Emulsification............. 14

Extrusion.....................

Extrusion Cooking.......... 15

Protein reactions........... 16

Changes in Proteins.......... 18

Protein Crosslinking......... 18 
Nonenzymatic Browning......... 19

2 JOURNAL ARTICLE.................... 21

Author's Title Page.......... 22

Abstract.................... 23

Introduction............... 24

Materials and Methods......... 25

Sample Preparation........... 25

Extrusion Conditions.......... 26

Proximate Analysis.......... 27

Hunter Color Values.......... 27

Nitrogen/protein solubility..... 27

Water Absorption............ 28

Emulsifying Properties......... 29

Analysis of data............ 30

Results and Discussion............ 30

Nitrogen solubility......... 30

Water Absorption............ 34

Emulsification........... 36

Hunter Color Values.......... 37

Conclusions.................. 38 
Literature cited............... 45

3 SUMMARY AND RECOMMENDATIONS.............. 49

summary ..................... 49

Recommendations................... 51

REFERENCES.......................... 54 


\section{List of Tables}

Table

Page

I. Composition of Pinto Beans Compared with other Dry Beans (in loogms edible portion)........... 7

II. Essential Amino Acid Composition of Pinto Beans Proteins $(g \backslash 16 \mathrm{~g} \mathrm{~N})$ Compared to whole Chicken Egg

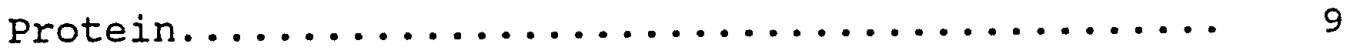

III. Functional Properties of Proteins and Their Mode of Action in Actual Food systems............... 12

1. Proximate Analysis of Pinto Beans Treated at Control, $80,100, \& 120^{\circ} \mathrm{C}$ on wet Basis............... 41

2. Effect of Extrusion Temperature on Water Absorption Capacity of Full fat flour at various pH levels... 42

3. Effect of Extrusion Temperature on Emulsification Capacity of Full Fat Flour at Various pH Levels.... 43

4. Effect of Extrusion Temperature on the Hunter Color Values in Full fat Pinto Bean Flours........... 44 


\section{List of Figures}

Figure Page

1. Effect of Extrusion Temperature on Nitrogen Solubility at different $\mathrm{pH}$ levels in Full Fat Pinto Bean Flour........40 


\section{Chapter I \\ Introduction and Review of literature \\ Introduction}

Worldwide shortage of good quality protein has prompted food scientists to investigate new methods of processing and utilizing plant proteins for human consumption. Among the plants investigated, legumes are now well recognized as an important source of dietary protein, particularly in the areas of the world where protein calorie malnutrition (PCM) is prevalent (Sathe et al., 1982).

The problem of PCM is prevalent in almost every developing country. It is the consensus among food scientists and nutritionists that an increased utilization of plant/vegetable proteins would overcome this malnutrition problem. Compared to animal proteins, legume or plant proteins are less expensive and less difficult to obtain. Legumes offer a wide variety of products besides dry seeds. Legumes in the immature stage are consumed as vegetables which are rich in carbohydrates and vitamins, while the mature seeds are a good source of fiber, proteins, minerals and vitamins. Legume proteins in general are deficient in methionine, but have higher levels of other nutritionally essential amino acids. Mature legume seeds are generally 
high in lysine which is deficient in most cereals. Legumes, in general, contain several anti-nutritional factors such as trypsin inhibitors, lectins, phytates, polyphenols and flatulence factors etc. These antinutritional factors are often inactivated or eliminated during fermentation or sprouting and cooking before consumption (Sathe et al., 1982).

At present, food legumes are processed in a variety of ways such as canning, milling, fermentation, roasting, puffing and preparation of the protein isolates and concentrates. However, significant amounts of vitamins and minerals are lost during thermal processing (Harper, 1989). The poor economic conditions in third world countries have limited the full use of the food processing equipment available on the market, which restricts the utilization of legumes to their fullest extent. To expose the consumer to a variety of foods which incorporate pinto beans as an ingredient, it is necessary to understand the processing conditions, required to use pinto beans in various legume based products.

Phaseolus vulgaris (pinto bean) is one of the most extensively studied legumes and is consumed in large quantites. It is widely cultivated in the temperate and the subtropical regions. It contributes to about $30 \%$ of the total production of the pulses and almost $50 \%$ of the 
production comes from Asia. When cooked, pinto beans have acceptable intrinsic properties such as flavor, color texture and nutritional properties. Based on the studies conducted on soybeans, pinto beans can be processed to an optimum quality to obtain requisite functional properties for intended applications (Hermannson, 1979).

Extrusion cooking, a high temperature short time food processing method, is used to transform a variety of raw materials into modified, intermediate, and finished products. Extrusion is performed under the conditions of heavy mechanical shear with high temperature and pressure conditions. The material is forced out of a die where a drop in pressure across the die results in puffing of the product. Because of their versatility, extruders have been used to make ready to eat cereals, sweet and salty snacks, dry and semi-moist pet foods, confectionary products, texturized vegetable protein and macaroni, etc (Harper, 1979).

Functional properties are studied to improve the consumer acceptability in the flavor, and texture of the product (Kinsella, 1979). The changes in the functional properties which occur as a result of processing should be studied in order to discover effective utilization of a ingredient in the food industry. Properties like solubility, water absorption capacity, emulsification, 
gelling and foaming are some important functional characteristics which should be understood for proper application of the ingredients.

\section{Objectives}

This study was initiated to evaluate high temperature, short time extrusion cooking on the functional behavior of full fat pinto beans. Specifically, the effect of extrusion temperatures $\left(80,100,120^{\circ} \mathrm{C}\right)$ on nitrogen/protein solubility, water absorption capacity, emulsification capacity at various $\mathrm{pH}$ 's $(3.0,4.5,7.0$, and 10.0), and the color of pinto bean flour were investigated.

\section{Significance of study}

Food scientists and nutritionists in recent years have recognized the value of plant proteins in supplying the protein needs of populations in developing and the underdeveloped countries where PCM exists (Salunke, 1982). Pinto beans are legumes which grow in tropical and semitropical areas where availability of good quality protein foods is limited (Salunke, 1989). Although the beans have high nutrition potential there has been a steady decline in the consumption of dry edible beans since the 1940's (United States Department of Agriculture 1978). The lack of convenience (time required to cook), associated with the preparation of the beans has been partially responsible for this trend (Aguilera et al., 1984). 
Most innovations in the processing of the beans involve the use of water (soaking, boiling and steaming) to prepare quick cooking beans, and instant whole bean powders (Aguilera et al., 1984). These innovations have disadvantages like significant energy being used in drying the final products, waste by-products containing high amounts of the organic matter, and smaller yields. Extrusion technology has led scientists to develop novel extruded food products as food ingredients or additives or as a final product because of its low-cost operation and large scale production. The final product formed is low in bulk, and therefore has lower transport costs, which affects the overall cost of the product.

Although many studies have been performed using soy beans, the database on the effect of extrusion cooking of pinto beans is still limited. It becomes important to study the functional properties, to understand the application of the pinto beans as a food ingredient in different foods products. The effect of extrusion temperature on the functional properties in pinto beans at several pH levels will help to explore the usage in pinto beans to their fullest extent.

This study was designed to investigate the effect of extrusion temperature on the protein functionality (solubility, water absorption capacity, emulsification 
capacity) at various $\mathrm{pH}$ levels and, finally, to investigate the change in color of the whole ground pinto beans at different temperatures.

\section{Review of Literature \\ Pinto Beans (Phaseolus vulgaris)}

Pinto beans (Phaseolus vulgaris) are one of the most widely cultivated and consumed food legumes in the temperate and semi tropical regions. The beans are used as a salad, as a vegetable, or as dry legumes, depending on their stages of maturity. The immature pods are marketed as fresh, frozen or canned, or as whole french beans. Mature ripe beans called navy beans, white beans, or northern beans are widely consumed (Salunke \& Kadam, 1989).

Phaseolus beans contribute nearly $30 \%$ of the total production of the pulses. They are grown in various countries, among which China ranks first in production followed by India, Mexico, U.S.A., and Brazil. The pinto beans are red or light brown in color.

\section{Composition}

Nutrient analysis of edible dry beans has been reported by several investigators (Sathe \& Salunke,1981; Kon et al., 1977). The proximate composition of the pinto beans, navy, Iima, and soy beans are shown in Table I. The proximate composition of pinto beans is similar to that of navy beans, Iima beans and soy beans. The crude protein content of 
Table I

Composition of pinto beans compared with other arv beans(in $100 \mathrm{~g}$ edible portion)

\begin{tabular}{|c|c|c|c|c|}
\hline & $\begin{array}{l}\text { Pinto } \\
\text { Beans }\end{array}$ & $\begin{array}{l}\text { Navy } \\
\text { Beans }\end{array}$ & $\begin{array}{l}\text { Soy } \\
\text { Beans }\end{array}$ & $\begin{array}{l}\text { Lima } \\
\text { Beans }\end{array}$ \\
\hline \multicolumn{5}{|l|}{ Proximate } \\
\hline \multicolumn{5}{|l|}{ Composition } \\
\hline Moisture (g) & 10.95 & 12.36 & 10.20 & 12.07 \\
\hline Protein (g) & 20.88 & 22.33 & 35.10 & 20.62 \\
\hline Fat $\quad(g)$ & 01.13 & 01.28 & 17.70 & 00.93 \\
\hline Carbohydrate (g) & 63.41 & 60.65 & 32.00 & 62.83 \\
\hline Fiber (g) & 06.01 & 05.52 & 04.20 & 05.71 \\
\hline \multicolumn{5}{|l|}{ Minerals } \\
\hline Calcium (mg) & 121 & 155 & 226 & 81 \\
\hline Potassium (mg) & 1328 & 1140 & 1504 & 1403 \\
\hline Iron (mg) & 05.88 & 06.44 & 08.50 & 06.19 \\
\hline \multicolumn{5}{|l|}{ Vitamins } \\
\hline Thiamin (mg) & 00.55 & 00.64 & 00.66 & 00.57 \\
\hline Riboflavin (mg) & 00.23 & 00.23 & 00.22 & 00.21 \\
\hline
\end{tabular}

Note: From "Composition of foods legume and legume products" by David B.Haytowitz, and Ruth H.Matthew, 1986, United States Department of Agriculture, Agriculture Handbook No. 8 Series. 
pinto beans is comparable to the navy beans and Iima beans, and is lower than soy beans. The fat content of the pinto beans is about 17 times lower than soy beans. The mineral content of pinto beans is higher than navy beans, but is slightly lower than lima and soy beans. The level of thiamin and riboflavin is comparable to lima beans, but slightly lower than soy and navy beans. proteins in Pinto Beans

Proteins present in the seeds of dry beans are primarily of two types: 1) Metabolic proteins (both enzymatic and structural) which are primarily responsible for normal cellular activities including the synthesis of structural proteins, and 2) storage proteins which provide a source of nitrogen and carbon skeleton for developing seeds during germination. Protein fraction data showed that the albumins and globulins are the predominant protein fractions present in Phaseolus vulgaris (Salunke, Sathe \& Deshpande, 1989). Guska and Khan (1991) studied the protein fractions from raw navy and pinto beans and also at different extrusion temperatures. The study revealed that globulins were about $39.32 \%$, followed by albumins (27.6\%), glutelins $(0.44 \%)$ and prolamins $(0.23 \%)$ of the total protein.

Table II shows the essential amino acid composition of the pinto bean proteins (Abdelmoyem et al.,1983) and whole 
Table II

Essential amino acid composition of the pinto bean proteins (g/16gN) compared to whole chicken egg protein.

\begin{tabular}{lcc}
\hline Amino Acid & Pinto Beans & Whole Chicken \\
& Proteins(a) & Egg Proteins(b) \\
\hline Lysine & 8.04 & 7.2 \\
Threonine & 4.73 & 5.2 \\
valine & 4.74 & 7.4 \\
Leucine & 8.74 & 7.8 \\
Isoleucine & 3.25 & 6.8 \\
Methionine & 2.03 & 3.4 \\
Tryptophan & 0.85 & 1.5 \\
Phenylalanine & 6.71 & 5.8 \\
Arginine & 8.11 & 6.7 \\
Histidine & 3.14 & 2.4 \\
& & \\
\hline
\end{tabular}

Note: From " Protein Isolates of Navy beans and Pinto beans:

Their uses in macaroni products". By Abdelmonem A.Seyam, J.B. Orville, and B.D. Merlin,1983, Journal or Agricultural and Food Chemistry, 31, page 499.

(b) From "Chemistry and Technology of Green Gram (Vigna radiata)" by R.N. Adsule, and D.K. Salunke, 1986, CRC critical Reviews in Food Science and Nutrition, 25, p.79. 
chicken egg protein (Salunke \& Adsule, 1986). Pinto beans show a relatively higher lysine content; pinto beans are commonly used in complementing cereal diets which are low in lysine (Abdelmonem et al., 1983).

\section{Functional Properties}

Protein isolates and protein concentrates prepared from various legumes are used as an ingredient in a variety of food products. These applications in different foods have been studied extensively and usage of these ingredients is based on the studies of the functional properties. According to Hermannson (1979) the knowledge of functional properties of proteins is necessary to determine the application of protein as an ingredient in different foods and to be utilized effectively in replacing ingredients in conventional foods.

The physical and chemical properties of proteins determine the functional properties (Mattil, 1971). According to Hermannson (1979) functional properties involve a balance of forces between those involving protein-protein, protein solvent and protein solute interactions which are in turn influenced by the nature of protein, and the presence of other ingredients in the food system in which the ingredient is added. Because of the physical and chemical nature of the protein, it is necessary to simulate the environmental conditions (e.g.,pH, temperature and ionic 
strength) to which proteins are exposed in food systems (Johnson, 1970).

solubility is an important functional property of proteins intended for beverages. Water absorption capacity, cohesion-adhesion, elasticity and fat absorption are important functional properties of proteins in the formulation of meats, sausages, soups and gravies. similarly emulsification capacity and viscosity plays an important role in certain meat formulations like sausages soups and juices. Important functional properties are listed in Table III to show the mode of action of soy protein and the food systems in which they are applied. Solubility

Nitrogen Solubility is a very important functional property intended for use in beverages as shown in table III. Nitrogen solubility influences other functional properties of emulsification, foaming, \& viscosity (Hermannson, 1979; Mattil, 1971). Solubility is expressed as Nitrogen solubility Index (NSI), water soluble protein, and protein dispersibility index (Kinsella, 1979). Solubility of proteins is affected by various environmental conditions including temperature, $\mathrm{pH}$ and ionic strength (Beuchat, 1979; Kinsella, 1979; Soluski et al., 1976). Increasing the temperature from $25^{\circ} \mathrm{C}$ to $60^{\circ} \mathrm{C}$ causes small increases in the solubility of soy protein isolates 
Table III

Functional properties of proteins and their mode of action in actual food systems

\begin{tabular}{|c|c|c|}
\hline $\begin{array}{l}\text { Functional } \\
\text { property }\end{array}$ & Mode of Action & Food system \\
\hline solubility & $\begin{array}{l}\text { Protein solvation, } \mathrm{pH} \\
\text { dependent }\end{array}$ & beverages \\
\hline $\begin{array}{l}\text { Water } \\
\text { absorption }\end{array}$ & $\begin{array}{l}\text { Hydrogen bonding of } \\
\text { water, entrapment of } \\
\text { water, no drip }\end{array}$ & $\begin{array}{l}\text { meats, sausages, } \\
\text { breads, cakes }\end{array}$ \\
\hline viscosity & $\begin{array}{l}\text { thickening, water } \\
\text { binding }\end{array}$ & soups, gravies \\
\hline Gelation & $\begin{array}{l}\text { protein matrix } \\
\text { formation, and setting }\end{array}$ & $\begin{array}{l}\text { meats, curds } \\
\text { cheeses }\end{array}$ \\
\hline Emulsification & $\begin{array}{l}\text { formation and } \\
\text { stabilization of fat } \\
\text { emulsions. }\end{array}$ & $\begin{array}{l}\text { sausages, } \\
\text { bologne, soup, } \\
\text { cakes }\end{array}$ \\
\hline Foaming & $\begin{array}{l}\text { forms stable films to } \\
\text { entrap gas }\end{array}$ & $\begin{array}{l}\text { whipped topping } \\
\text { chiffon desert, } \\
\text { angel cakes }\end{array}$ \\
\hline
\end{tabular}

Note: From " Functional Properties of Soy Beans"by

J.E.Kinsella, 1979, Journal of American Oil

Chemists' Society, $\underline{56}$, p.245. 
(Kinsella, 1979). However heat treatment at or near $100^{\circ} \mathrm{C}$ reduces solubility due to protein denaturation. In some cases, denaturation and solubility are not always correlated. The $\mathrm{pH}$ solubility profiles show a decrease in solubility of soy proteins with an increase in $\mathrm{pH}$ from 2.0 to 4.5 , from 4.5 to 10.0 there is a gradual increase in nitrogen solubility and a decrease in solubility beyond that. According to Kinsella, (1979) and Mattil (1971) solubility of most plant proteins is lowest at isoelectric point ( $\mathrm{pH} 4.5)$.

\section{Water Absorption Capacity}

Water absorption capacity is a functional property that is important in meats and sausages, breads and cakes where entrapment of water takes place. WAC is dependent upon the protein water interactions (Sathe et al., 1984). This property is an important attribute in preparation of baked foods (Kinsella, 1979). Kinsella (1976) observed that water absorption capacity was influenced by temperature and $\mathrm{pH}$. Heat treatment enhances the water absorption capacity of soy flour, and there was a six fold increase when $\mathrm{pH}$ shifted from 5.0 to 7.0 . Sathe et al. (1982), theorized that the increase in water absorption capacity may be due to the exposure of water binding sites on the side chains of proteins which were blocked in the lipophilic environment. 
Emulsification capacity

The emulsion properties are related to the capacity of the proteins to lower the interfacial tension between the hydrophobic and the hydrophillic components of the food systems. The ability of proteins to aid the formation and stabilization of an emulsion is critical for many' applications, i.e., cake batters, coffee whiteners, salad dressings and frozen deserts (Kinsella, 1979). The emulsion capacity of soluble proteins depends upon the hydrophillic and the lipophillic balance which is affected by $\mathrm{pH}$ (Sathe et al., 1982). The emulsification capacity curve at various $\mathrm{pH}$ resembles the solubility curve of the proteins (Crenweldge et al.,1974), and alkaline $\mathrm{pH}$ improves the emulsification capacity ( $\mathrm{Lin}$ et al., 1974). In foods,like mayonnaise, stability of the emulsion is critical and is dependent upon $\mathrm{pH}$ which is a minimum at $\mathrm{pH} 4.5$ (isoelectric point) in which protein molecules tend to aggregate and destabilize the interfacial membrane (Franzen \& Kinsella, 1976). The stability of the emulsion is also influenced by the protein fractions; the globular proteins form a highly cohesive film which is resistant to mechanical deformation, thereby preventing coalescence (Sathe et al., 1982).

\section{Extrusion}

The extrusion process dates back well over a century. Initially its role was limited to mixing and forming 
macaroni and ready to eat cereals (Mercier et al., 1989). The early extruders had a piston contained in a cylinder and was capped with a shaping orifice to produce batches of pasta or spaghetti. The replacement of the piston with the continuously rotating helical screw resulted in the development of a high temperature short time cooker that transformed a variety of raw materials to intermediate and finished products. The high demand for increased production and quality led to the development of the extruder with an emphasis on: 1) continuous high throughput processing; 2) energy efficiency; 3) processing of relatively dry viscous products; 4) improvement of color and texture; 5) control of thermal changes of food constituents; and 6) use of unconventional ingredients (Harper, 1989). Extrusion cooking

Extrusion cooking is defined as the process by which moistened expanding starchy and proteinaceous materials are plasticized in a tube by a combination of moisture, pressure, temperature and mechanical shear (Hauck \& Huber, 1989).

The first commercially extruded expanded food products, corn snacks, were produced using single screw extruders (Hauck \& Huber, 1989). Because of the temperature and the moisture conditions, an exothermic post die expansion of the product takes place, resulting in a light crisp product. 
The first application of the single screw extruders was in the early 1950's when dry pet foods were produced commercially in the United States (U.S). The 1960's brought the first commercial production of dry expanded ready to eat cereals using a single screw extruder. Extrusion technology advanced in the 1970 's to produce texturised vegetable protein which is very much acceptable today. In the 1980's there was a rapid commerciallization of production of feeds for aquatic species using extrusion. In 1987 the total commercial retail value of extruded products in the U.S.A. was $\$ 2.95$ billion dollars. According to Hauck and Huber, (1989), continued research and better understanding of the extrusion process, raw material characteristics and behavior as well as energy and labor economics, are needed to work together to increase the number of marketable products using extrusion cooking.

\section{Protein Reactions During Extrusion Processing}

Extrusion of proteinaceous materials exposes proteins to high temperatures and high pressures, and a mechanical shear combines to convert the soy meal to a continuous plastic melt (Harper, 1979). The melt travels down the barrel with the protein molecules aligned parallel to the barrel and when forced through the die, it drops to atmospheric pressure, releasing steam which makes it porous. The material is cut and dehydrated, and, after rehydration, 
it gives a meat like consistency (Stanley, 1989).

Currently full fat soy meal is the only commercially important starting material used in extrusion (stanley, 1989) and is the common starting material for the production of meat analogs. Sheard et al.(1985) found that an extrudate from soy protein isolate ( $91 \%$ protein) had a larger diameter and a higher shear value than that from soy flour $(50 \%)$.

The storage proteins of plants differ considerably from most other protein systems such as animal proteins, with which food scientists work. In plants they exhibit a quaternary structure of higher molecular weight subunits partially stabilized by hydrophobic hydrogen bonding among non polar residues. Soy ingredients are a multicomponent system where carbohydrates account for up to $30 \%$ of the total soy meal based feed materials. Changes in Proteins During Extrusion

Extrusion cooking acts on the proteins both physically and chemically. Physically, extrusion converts protein bodies into a homogenous matrix; chemically the process recombines storage proteins into structured fibers (stanley, 1989).

Extrusion exposes the proteins to combined heat, pressure and shear. Cheftel et al.(1985) found that a severe thermal treatment of proteins resulted in structural 
changes such as hydrolysis of peptide bonds, modification of amino acid side chains and formation of new isopeptide crosslinks. Shibasaki et al.(1969) employed a series of reagents to selectively solubilize heat denatured proteins from defatted soy meal, and little protein could be extracted with the use of water and buffers at different $\mathrm{pH}$ levels, which relates to the loss in solubility. However, Maga and Sizer (1979), measured the reactivity of naturally occurring free amino acids in potato flakes and found that there was a considerable decrease in phenylalanine, tyrosine, serine, isoleucine and lysine at $70^{\circ} \mathrm{C}$ at $160^{\circ} \mathrm{C}$. The total loss of these amino acids was $89 \%$. At $100^{\circ} \mathrm{C}$ and $130^{\circ} \mathrm{C}$ extruded potato flakes had higher levels of free amino acids, and it is postulated that hydrolysis of protein occurs at elevated temperatures.

\section{Protein Crosslinking}

According to stanley, (1989) protein crosslinking occurs during extrusion processing, which leads to changes in the covalent disulphide links to non-disulphide links. This crosslinking leads to major functional, such as changes in solubility, water absorption capacity, emulsifying and foaming properties and nutritional changes in the food systems such as isopeptide formation, loss of lysine by the formation of Iysinoalanine, and collagen formation. 
lathionine types of protein crosslinks results from condensation and $\beta$-elimination reactions of amino acids in the presence of bases and heat. Jeunink \& Cheftel (1979) were unsuccessful in analyzing any of these compounds. Non Enzymatic Browning During Extrusion Processing

The possibility of non-enzymatic browning arises from the Maillard reaction occurring between $\epsilon$-amino groups of protein bound lysine and an aldose or a ketose reducing sugar. The conditions of high temperature and low water activity favors this reaction and leads to protein polymerization (Labuza et al.,1977).

The processing conditions used during extrusion cooking, i.e., high temperature and low water content, favors Maillard reaction. Nonenzymatic browning is desirable in baked products to provide a golden crust. However, excessive browning results in an undesirable color and flavor. Maximum browning occurs between a water activity of 0.3 and 0.7 , depending on the type of the food (Labuza et al.,1977). Products high in starch may not even require sugar as starch hydrolysis will make the reducing sugars available and facilitate Maillard browning (Berset, 1989). Factors such as screw configuration and size of the die opening, influence the color of the product; for instance, a large puffing or expansion with a large surface area "dilute" the pigments, and the product appears lighter 
(Maga \& Cohen, 1978).

starchy materials such as cowpea and mung beans show an increase in the reducing sugars during extrusion cooking as a result of starch dextrinization (Pham \& Del Rosario, 1984). Extrusion of mixtures containing proteins and a potential source of reducing sugars (sucrose) result in losses of up to $40 \%$ lysine depending on the water content and the temperature. 
21

CHAPTER 2

JOURNAL ARTICLE 


\title{
EFFECT OF EXTRUSION TEMPERATURE ON THE COLOR AND FUNCTIONAL PROPERTIES OF FULL FAT PINTO BEAN FLOUR
}

\author{
Arvind Bansal, Panfilo S. Belo*, Lucy McProud, \\ and Miriam Saltmarch \\ Department of Nutrition and Food science \\ San Jose State University \\ 1 Washington Square \\ San Jose, CA 95192
}

* Address questions and comments to: Dr. Panfilo

Belo, Department of Nutrition and Food Science, San Jose

State University, 1 Washington Square, San Jose, CA 95192, (408) 924-3108. 
ABSTRACT

Full fat flour prepared from whole pinto beans was extruded in a single screw extruder in a form of a dough with $40 \%$ moisture. Extrusion was performed at 80, 100, $120^{\circ} \mathrm{C}$. Extrudates were dried at $45^{\circ} \mathrm{C}$, ground to pass through a 40 mesh seive. The resulting products were analysed for proximate composition, color and functional properties and compared against the unextruded full fat pinto bean flour (control). Nitrogen solubility (NS), water absorption capacity (WAC), and emulsification capacity (EC) were determined at various $\mathrm{pH}$ levels. No significant difference was observed in the protein content of the unextruded (control) and the extruded pinto bean flour. While the control showed a typical NS-pH profile, extrusion at various temperatures lowered the NS. In general at constant $\mathrm{pH}$, WAC decreased as the extrusion temperature was increased. EC-pH data showed similarities to the NS-pH profile, although there was a decrease in EC with increasing temperature, this effect was observed at all pH levels but 10.0. The flour got significantly darker at $120^{\circ} \mathrm{C}$ than at 80 and $100^{\circ} \mathrm{C}$ compared to the control as shown by the data from Hunter color values. Overall there was a decrease in functionality with increasing extrusion temperature. 


\section{Introduction}

The pinto bean (Phaseolus vulgaris) is an important source of protein in the developing and underdeveloped countries and is used in the U.S., as a part of Mexican cuisine. Legumes are an important source of plant protein for human consumption and are also one of the least expensive and most convenient source of high protein materials available to complement the amino acid deficiency of cereal proteins. It is well known that pinto beans have relatively high protein and lysine contents (Abdelmonem et al. , 1983)

Pinto beans have traditionally been prepared by soaking and cooking at home or consumed as commercially processed canned beans. Whole beans require soaking and cooking to insure uniform expansion of the seed coat and hydration of the cotyledon matrix. Long cooking times to achieve satisfactory palatability have impeded the further utilization of pinto beans (Lee et al.,1983). It is believed that commercial use of pinto beans could be expanded if they were available as shelf stable flours. A continuous cooking process such as extrusion cooking is an important unit operation in protein and starch technology in products like macaroni, pasta spaghetti (Abdelmonem et al., 1983), and appears to be a suitable method for the 
production of shelf stable flours. During extrusion the starches in foods are gelatinized and manufactured into foods such as snacks and breakfast cereals. Similarly the proteins are denatured and restructured into fibrous structures that resemble meat upon hydration. The product is low in moisture $(15 \%-30 \%)$ and requires a minor air drying to produce a shelf stable product.

Although effects of heat on solubility of navy and pinto beans have been studied (Aguilera et al.,1984;Guzka and Khan, 1991; Pilosof et al., 1981), limited research has been done to determine the effects of high temperature extrusion on the solubility, water absorption capacity and emulsification capacity of full fat flour. This data on the functionality of full fat pinto bean flour is needed, to use pinto beans as an ingredient in food systems (Hermannson, 1979). The extrusion processing leads to changes in the functionality, and there is a need to expand the database on the changes in functionality that occur during extrusion. The purpose of this investigation was to study the effect of high temperature extrusion on nitrogen solubility, water absorption capacity, and emulsification capacity of full fat pinto bean flour processed at different temperatures and various $\mathrm{pH}$ levels.

MATERIALS AND METHODS

sample and sample Preparation. Pinto bean samples used 
in this study were purchased from the local grocery store. The beans were ground in a straub model $4 \mathrm{E}$ grinding mill (Straub Co. Phila, PA). The flour was sieved through a 40 mesh sieve, collected in polyethylene food bags and stored at room temperature.

Extrusion conditions. Extrusion was performed on a Laboratory size Killion single screw extruder (Killion Corporation, New Jersey). The extruder had a $1 / 2$ inch bore size, and a 22 inch barrel length. The barrel consisted of four temperature zones, which could be controlled individually, using controls on the control panel. The screw is 18 inches long, and 1 inch pitch per screw.

The full fat pinto bean flour was made into a dough to a final moisture content of $40 \%$ using a Kitchen Aid dough maker, and then extruded. The extrusion conditions involved were as follows: the screw speed was $75 \mathrm{rpm}$; the dough was extruded at $80^{\circ} \mathrm{C}$, the second run at $100^{\circ} \mathrm{C}$, and the third at $120^{\circ} \mathrm{C}$ in duplicates. To obtain the extrudate subjected to uniform temperature, the initial portion of the extrudate equal to the length of the barrel was discarded; the extrudate was dried in a convection air oven at $40^{\circ} \mathrm{C}$ for 24 hours, and ground in a straub Model $4 \mathrm{E}$ grinding mill, to pass through a 40 mesh. The dried extrudate was stored in polyethylene bags in the dark at room temperature until further analysis. 
Analytical Methods. The functional properties were performed at several $\mathrm{pH}$ levels $(3.0,4.5,7.0,10.0)$, to understand the applicability of the food ingredients in different food systems at different $\mathrm{pH}$ levels.

Proximate Analysis. Analysis of crude protein, crude fat, ash and moisture were performed according to the methods of Association of the Official Analytical Chemists (1984). The total carbohydrate was obtained by difference. Hunter Color Value Determination. The Hunterlab Model D25-A color meter was used to determine the difference in the color in the whole bean flour and the extrudates. The instrument was standardized using a white tile at $L=92.1$, $a=-0.8, b=-0.7$. The flour from each of the treatments was placed in a petri dish and the $1, a$, and $b$ values were obtained. The analysis was performed in triplicates and means of the data obtained were reported. The machine was standardized after each replicate.

Nitrogen/Protein solubility. The protein solubility was determined using the Kjeldahl nitrogen determination described by Morr et al.(1985) with minor modifications. The sample $(2.5 \mathrm{~g})$ was weighed to the nearest $0.1 \mathrm{mg}$ in a 50 $\mathrm{ml}$ flask, and $30 \mathrm{ml}$ of $0.1 \mathrm{~N} \mathrm{NaCl}$ solution was added with continuous stirring using a magnetic stirrer to form a dispersion. The $\mathrm{pH}$ of the dispersion was adjusted to the $\mathrm{pH}$ $3.0,4.5,7.0$, and 10.0 using $0.1 \mathrm{~N} \mathrm{HCl}$ or $\mathrm{NaOH}$. The 
dispersion was stirred for an hour using a GCA Precision Scientific stirrer at a setting that does not produce a vortex. After one hour of stirring the volume was made to $50 \mathrm{ml}$ with $\mathrm{NaCl}$ solution. The dispersion was centrifuged (IEC Damon Division Model B2OA, Mass.) under refrigeration at $1900 \mathrm{~g}$ (Head \#872 Spec. $6 \times 250 \mathrm{ml}$, angle) for $30 \mathrm{~min}$ and filtered through a whatman No. 1 filter paper. Ten ml of the filterate was analysed for nitrogen. The amount of nitrogen in the filtrate was determined using Kjeldahl (AOAC, 1984). The percent nitrogen solubility was calculated by dividing the total nitrogen in the filterate by the total nitrogen present in $2.5 \mathrm{~g}$ of the sample multiplied by 100.

Water Absorption Capacity. Water absorption capacity was determined in triplicate at $\mathrm{pH} 3.0,4.5,7.0$ and 10.0 using the method described by Sathe et al. (1982) with modifications. A $1.0 \mathrm{~g}$ sample was weighed into a graduate centrifuge tube and mixed with about $25 \mathrm{ml}$ of water in a mixer Vortex (Fisher Scientific Model 231). The $\mathrm{pH}$ was adjusted using $0.1 \mathrm{~N} \mathrm{HCl}$ or $\mathrm{NaOH}$ solution, and the volume increased to $30 \mathrm{ml}$ using distilled water. The dispersion stood at room temperature for 30 minutes, and was centrifuged at $7000 \mathrm{rpm}$ in a table top clinical centrifuge (Damon/IEC division) for 30 minutes. The supernatant was discarded, and the walls of the tube were dried carefully using an absorbing tissue. The tube was weighed again, and 
the gain in weight was recorded. The mean values of triplicate determinations at each $\mathrm{pH}$ were determined as gram of water absorbed per gram of sample.

Emulsification capacity. The method used in the determination of emulsification capacity was essentially that of Beuchat et al. (1975) with minor modifications. A $0.1 \mathrm{~g}$ of the sample was weighed in a glass tube (length 10 $\mathrm{cm}$ diameter $2.5 \mathrm{cms}$ ) and $4 \mathrm{ml}$ of distilled water was added and mixed. The $\mathrm{pH}$ was adjusted using a $\mathrm{pH}$ meter to the desired level using $0.1 \mathrm{~N} \mathrm{HCl}$ or $\mathrm{NaOH}$ and the final volume was made to $5 \mathrm{ml}$ with distilled water. The dispersion was blended in a Virtis "45" (Gardiner, New York) tissue homogenizer at a speed of 0.5 (the maximum speed of the instrument being 11.0). The instrument has a four blade impeller of 0.5 inch diameter. Refined corn oil was added to the dispersion from a burette in $1.0 \mathrm{ml}$ increments. The mixture was blended for 20 secs, and allowed to stand at room temperature for $1 \mathrm{~min}$, and the break in the emulsion was observed. The procedure was repeated until the break in emulsion and the volume of oil used was noted. The break in emulsion is defined subjectively as that point when the emulsion coalescence broke to yield a liquid separation and a change in consistency. Triplicate determinations at each pH were made. The emulsification capacity was expressed as $\mathrm{ml}$ of oil used per gm of sample. 
Analysis of Data. All determinations in this study were performed in triplicate. The statistical analysis of the data was done using sPSS computer software (SPSS Inc. Chicago, Illinois).

\section{REBULTS AND DIBCOSSION}

Proximate Analysis. Proximate compositions of the unextruded (control) and the extruded full fat pinto bean flour on a wet basis are shown in Table 1 . On a dry weight basis, crude protein, crude fat, ash and total carbohydrate contents of unextruded (control) full fat flour were $23.8,1.3,3.3$ and $71.4 \%$, respectively. These values are within the range of the values reported in the literature (Sathe and Salunke, 1989). Based on the moisture values, the dry matter content of the flour extruded at $120^{\circ} \mathrm{C}$ was significantly higher than the control and those that were extruded at 80 and $100^{\circ} \mathrm{C}$. Aside from moisture and dry matter contents of the flour extruded at $120^{\circ} \mathrm{C}$, there was no significant difference in the proximate composition of control and extruded full fat pinto bean flours. The relatively high protein, total mineral, total carbohydrate, and low fat content make extruded pinto bean flour an attractive ingredient for food formulations. Nitrogen/ Protein Solubility (NS).

Figure 1 shows the nitrogen solubility profile of the unextruded (control) and extruded full fat pinto bean 
flours. As expected the $\mathrm{pH}$ dependency of nitrogen solubility was apparent in both extruded and unextruded samples. Unextruded pinto bean flour showed a typical protein/nitrogen solubility-pH profile where nitrogen solubility decreased slightly from $\mathrm{pH} 3.0$ and 4.5 , and increased significantly thereafter up to $\mathrm{pH}$ 10.0. A maximum of $77.0 \%$ and a minimum of $14.0 \%$ nitrogen solubility were obtained for unextruded pinto bean flour at $\mathrm{pH} 10.0$ and 4.5 , respectively.

Extrudates obtained at 80,100 , and $120^{\circ} \mathrm{C}$, on the other hand, showed a slightly different profile and the extent of nitrogen solubility change appeared to be dependent on the extrusion temperature. At a given extrusion temperature nitrogen solubility increased as the $\mathrm{pH}$ of the extracting medium was increased. While there was no significant difference in the nitrogen (protein) content of unextruded and extruded pinto bean flours (Table 1), a significant $(p \leq 0.05)$ decrease in nitrogen solubility resulting from extrusion at 80 and $100^{\circ} \mathrm{C}$ was observed. Extrudates at $80^{\circ} \mathrm{C}$ had significantly $(p \leq 0.05)$ lower nitrogen solubility than the control at $\mathrm{pH} 4.5,7.0$ and 10.0 , but no significant difference was observed at $\mathrm{pH} 3.0$. Extrusion at $100^{\circ} \mathrm{C}$ further decreased nitrogen solubility of full fat pinto bean flour. The extrudates at $100^{\circ} \mathrm{C}$ had significantly ( $\left.p \leq 0.05\right)$ lower nitrogen solubility than the control and the 
extrudates at $80^{\circ} \mathrm{C}$. This insolubilization of protein as evidenced by the decrease of nitrogen solubility is consistent with the data reported by several investigators on the effect of extrusion temperature on protein solubility. Pham and Del Rosario (1984) observed that the effect of $\mathrm{pH}$ on nitrogen solubility index (NSI) of soy, cowpea, and mung beans is extrusion temperature dependent. They reported that at a given extrusion temperature, NSI increased with increasing $\mathrm{pH}$ of the extracting medium. on the other hand they further indicated that at a given $\mathrm{pH}$, NSI decreased with increasing extrusion temperature and the degree of insolubilization of the protein varied from one bean to another. Gujska and Khan $(1990,1991)$ reported that while there was no significant difference in the nitrogen protein content of unextruded and extruded pinto bean flours, extrusion caused a significant decrease in water and salt extractable proteins and significantly increased in insoluble nitrogen compounds.

While the nitrogen insolubilization effect at 80 and $100^{\circ} \mathrm{C}$ is obvious, the extrudates at $120^{\circ} \mathrm{C}$ showed a different pattern in nitrogen solubility. Extrusion at $120^{\circ} \mathrm{C}$ produced extrudates with significantly ( $p \leq 0.05)$ higher nitrogen solubility than extrudates at 80 and $100^{\circ} \mathrm{C}$. Maga and Sizer (1979) found an increase in the levels of free amino acids in potato flakes when extruded at $100 \& 130^{\circ} \mathrm{C}$ compared to 
the extrudates treated at $70^{\circ} \mathrm{C}$. They attributed these high free amino acid values to the hydrolysis of peptides, shearing of protein or rupturing of intact cellular organelles which in turn release proteolytic enzymes and free amino acids at these temperatures. Furthermore, while the effect of extrusion at 80 and $100^{\circ} \mathrm{C}$ on nitrogen solubility is a sign of denaturation and insolubilization of protein, according to Hermannson (1979) denaturation and solubility are not always correlated. She showed that high solubility data are sometimes obtained from completely denatured soy proteins. According to Kinsella (1979), while high protein/nitrogen solubility, generally indicates low heat treatment and good functionality, it may in some instances be misleading. Soy protein that has been heated above $120^{\circ} \mathrm{C}$ or exposed to alkali ( $\mathrm{pH}$ 11) for some time may be very soluble, but its functional properties may be impaired because of disaggregation and hydrolysis of proteins (Ishino and Ikamoto, 1975).

The significance of protein solubility in certain food products such as beverages, soups, etc., is now well recognized. High protein solubility is also related to other functional properties such as emulsification, viscosity, and foaming capacity, etc., (Hermannson, 1979). Based on the solubility data obtained it appears that the application of extruded pinto bean flour as a food 
ingredient in food products where protein solubility is desired, will depend upon the $\mathrm{pH}$ of the product and the temperature of extrusion.

Fater Absorption Capacity (WAC). WAC of unextruded (control) and extruded full fat pinto bean flour are shown in Table 2. As can be observed, WAC of the control and extruded samples are $\mathrm{pH}$ dependent and the extent of change due to extrusion varied with temperature. The WAC of unextruded pinto bean flour decreased as $\mathrm{pH}$ of the medium was increased from 4.5 to 10.0. While there was no significant difference in WAC of unextruded flour at $\mathrm{pH} 3.0$ and 4.5 , significantly $(p \leq 0.05)$ lower WAC values were obtained at $\mathrm{pH} 7.0$ and 10.0. The WAC value of the unextruded sample was $237 \%(2.37 \mathrm{~g}$ water $/ \mathrm{gm}$ of sample) and was maximum at $\mathrm{pH} 4.5$. Extrusion at $80^{\circ} \mathrm{C}$ resulted in extrudates with significantly $(p \leq 0.05)$ lower WAC at $\mathrm{pH} 3.0$, 4.5 and 10.0 than that of the control. No significant difference was noted at $\mathrm{pH} 7.0$. Further reduction in WAC was observed at $100^{\circ} \mathrm{C}$. Extrudates at $100^{\circ} \mathrm{C}$ have significantly $(\mathrm{p} \leq 0.05)$ lower WAC at all pH levels than the control. Significant $(p \leq 0.05)$ reductions in WAC were observed at $\mathrm{pH} 7.0$ and 10.0 when extrusion temperature was increased from 80 to $100^{\circ} \mathrm{C}$. However, there were no significant difference in WAC of 80 and $100^{\circ} \mathrm{C}$ extrudates at $\mathrm{pH} 3.0$ and 4.5 . The extrusion at $120^{\circ} \mathrm{C}$ significantly 
$(\mathrm{p} \leq 0.05)$ reduced the WAC compared to the control, at $\mathrm{pH} 3.0$, 4.5 and 7.0 levels but not at $\mathrm{pH} 10.0$. Extrudates at $120^{\circ} \mathrm{C}$ showed no significant difference $(p \leq 0.05)$ compared to $100^{\circ} \mathrm{C}$ at $\mathrm{pH} 3.0$ and 7.0 while as at $\mathrm{pH} 10.0$ the WAC values significantly increased compared to the extrudates at $100^{\circ} \mathrm{C}$. The presence of polysaccharides (pinto beans 64-68\%) could lead to differences in the WAC values, since hydrophillic polysaccharides absorb more water than protein alone. Table 1 shows the amount of carbohydrates present in the unextruded and the extruded pinto bean flour samples. It is assumed that the decrease in the WAC values may be attributed to the dextrinization of polysaccharides present in the flour. Colonna et al (1989) indicated that water absorption capacity tends to decrease with the onset of dextrinization. Hutton \& Campbell (1977), indicated that polysaccharides could compete with other system components, protein in this case, for available water.

The significance of water absorption capacity in certain food products such as semimoist pet foods, protein concentrates etc is well recognized. High WAC is important in maintaining the adequate moisture level in foods where water is not being added. Based on the WAC data, it appears that the application of the extruded pinto bean flour as food ingredients in food products where WAC is desired will depend upon the $\mathrm{pH}$ of the product, the amount of total 
carbohydrates, and the temperature of extrusion.

Emulsification Capacity (EC). Data presented in Table 3 shows EC of unextruded and extruded full fat pinto bean flour. As expected the values vary with $\mathrm{pH}$. At a given temperature the EC-pH relationship seemed to follow a similar pattern with protein solubility $\mathrm{pH}$ profile (Figure 1) where EC increases as the $\mathrm{pH}$ of the medium is increased. A similar relationship was observed by Narayana and Narsingarao (1982) on winged bean flour indicating that the increase in EC at higher $\mathrm{pH}$ is due to the increase in protein solubility. At a given $\mathrm{pH}$, there is a significant change in EC resulting from extrusion at different temperature. Extrusion at $80^{\circ} \mathrm{C}$ resulted in extrudates with significantly $(\mathrm{p} \leq 0.05)$ higher EC than the control at $\mathrm{pH}$ $3.0,4.5,7.0$ and 10.0. Extrusion at $100^{\circ} \mathrm{C}$ decreased the EC significantly $(\mathrm{p} \leq 0.05)$ at $\mathrm{pH} 3.0,4.5$, and 7.0 , whereas no change was observed at $\mathrm{pH} 10.0$, compared to the control. Extrudate at $120^{\circ} \mathrm{C}$ showed a significantly $(p \leq 0.05)$ lower EC than the control at $\mathrm{pH} 3.0,4.5 \& 7.0$, while no change in EC was observed at $\mathrm{pH}$ 10. It appears that the functionality relationship of nitrogen solubility and emulsification capacity does not occur as the extrusion temperature increases. As indicated earliar, solubility of extrudate obtained at $120^{\circ} \mathrm{C}$ was higher at $\mathrm{pH} 7.0$ compared to the ones treated at 80 and $100^{\circ} \mathrm{C}$, while as the EC was higher at $80^{\circ} \mathrm{C}$ 
and lower at 100 and $120^{\circ} \mathrm{C}$ at $\mathrm{pH} 7.0$, indicating that emulsification does not deperd on the solubility of the protein. The EC values for temperature treatment at $80^{\circ} \mathrm{C}$ are significantly higher at all $\mathrm{pH}$ levels compared to the control, 100 and $120^{\circ} \mathrm{C}$. It is assumed that the extrusion temperature of $80^{\circ} \mathrm{C}$ led to the dextrinization of the polysaccharides, exposing more of the hydrophillic and the hydrophobic areas on the protein surfaces while the temperature did not effect the protein itself, because a high emulsification is observed in the pinto bean flour. At 100 and $120^{\circ} \mathrm{C}$ it appeared that there was denaturation of the protein which led to decreased emulsification. MCwatters and Holmes (1979) showed that emulsion capacity response to moist heat was similar to the nitrogen solubility response and that both of these functional properties decreased as the temperature increased.

The significance of emulsification capacity in certain food products such as mayonnaise, coffee whiteners, salad dressings is well recognized. Based on the EC data obtained it appears that the application of extruded pinto bean flour as food ingredients in places where EC is desired will depend on the $\mathrm{pH}$ and temperature of extrusion.

Hunter color Values. Effect of extrusion temperature on the color of the extrudates are shown in Table 4 . In general there was a decrease in lightness, redness and an 
increase in yellow color of the pinto bean flour as the temperature was increased from 80 to $120^{\circ} \mathrm{C}$. The "L" value decreased by $10.3 \%$ at $80^{\circ} \mathrm{C}$ and then was further reduced by $15.4 \%$ as the temperature increased from 80 to $120^{\circ} \mathrm{C}$. The "a" value decreased by $88.5 \%$ at $120^{\circ} \mathrm{C}$ where the "a" value changes to a negative value which means that the color of the product changed from red to green color. The "b" value increased by $48.3 \%$ at $120^{\circ} \mathrm{C}$ which indicates an increase in yellow color of the flour significantly $(p<0.05)$. Noguchi and cheftel (1983) reported that the brown color of the protein enriched cookies at $13 \%$ water increased significantly with increasing extrusion temperature from 170 to $210^{\circ} \mathrm{C}$. The browning occurred due to non-enzymatic browning at high temperature and low water content which favors Maillard reaction. Shagun and Harper (1980) showed that cereal mixtures extruded without added sugars may contain reducing sugars upon starch hydrolysis induced by mechanical shear during extrusion, enhances the Maillard browning even without adding any reducing sugars. Factors, such as screw configuration, and size of the die opening, can significantly influences the product color (Maga \& Cohen, 1978).

\section{CONCLUSIONS}

Extrusion of full fat pinto bean flour at $40 \%$ moisture did not affect the protein content of the flour. The color 
of the flour became darker when extruded at $120^{\circ} \mathrm{C}$. The visual appearance of the flour was acceptable. The solubility of the protein was effected by the $\mathrm{pH}$ of the dispersion medium. Maximum solubility of $74.09 \%$ was observed at $\mathrm{pH} 10.0$ extruded at $120^{\circ} \mathrm{C}$, and the lowest solubility of $8.2 \%$ was observed at $100^{\circ} \mathrm{C}$ at $\mathrm{pH} 3.0$. The extrusion temperature of $100^{\circ} \mathrm{C}$ was seen to be the most detrimental to the solubility of pinto bean proteins. This low solubility at $100^{\circ} \mathrm{C}$ limits its use in food systems which require high solubility (e.g.beverages, soups etc.). Extruded samples of full fat pinto bean flour showed a maximum solubility at $120^{\circ} \mathrm{C}$ at $\mathrm{pH} 7.0$. Unextruded pinto bean flour absorbed 2.3 times its weight of water at pH 4.5 . Extrusion decreased the WAC values, but still a maximum of twice the weight of pinto bean flour of water was absorbed at 80 and $100^{\circ} \mathrm{C}$ at $\mathrm{pH} 3.0$ and 4.5 respectively. The lowest of the WAC values were observed at $100^{\circ} \mathrm{C}$ at $\mathrm{pH} 10.0$ (i.e., $1.27 \mathrm{~g}$ of water $/ \mathrm{g}$ of sample). The EC values were not related directly to the solubility, although there was some trend observed in the unextruded samples. In general treatment at $80^{\circ} \mathrm{C}$ showed high EC values, the maximum EC being $259 \mathrm{ml}$ of oil absorbed / $\mathrm{g}$ of the sample at $\mathrm{pH} \mathrm{7.0,} \mathrm{and} \mathrm{the} \mathrm{lowest} \mathrm{EC}$ values were obtained at $120^{\circ} \mathrm{C}$ at $\mathrm{pH} 3.0(19.3 \mathrm{ml}$ of oil/ $\mathrm{g}$ of the sample). A high NS value at the same temperature and pH may not affect the functional properties directly. 


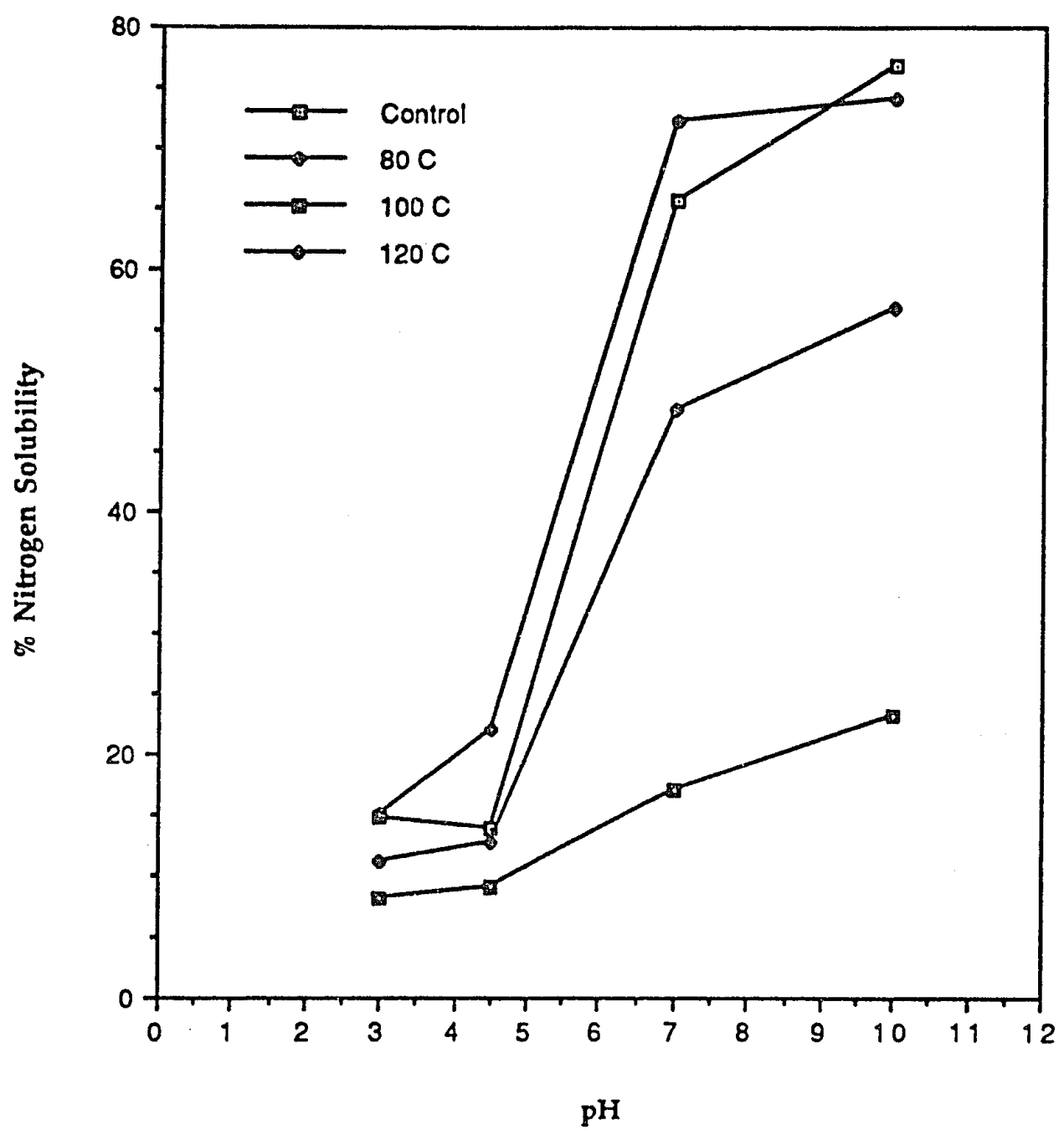

Figure 1. Effect of Extrusion Temperature on the Nitrogen Solubility at different $\mathrm{pH}$ values. 
Table 1. Proximate Composition of Unextruded (Control) and Extruded Full Fat Pinto Bean Flour

\begin{tabular}{|c|c|c|c|c|}
\hline \multirow[b]{2}{*}{ Composition } & \multicolumn{4}{|c|}{ Extrusion temperature $\left({ }^{\circ} \mathrm{C}\right)^{a}$} \\
\hline & Control & 80 & 100 & 120 \\
\hline protein $^{b}(\%)$ & $21.4 \pm 0.02$ & $20 \cdot 5 \pm 1.4$ & $20.7 \pm 0.7$ & $20.9 \pm 0.1$ \\
\hline Crude Fat $(\%)$ & $1.2 \pm 0.2$ & $1.1 \pm 0.1$ & $1.2 \pm 0.1$ & $1.2 \pm 0.2$ \\
\hline Ash $(\%)$ & $3.0 \pm 0.1$ & $3.0 \pm 0.1$ & $3.0 \pm 0.1$ & $2.9 \pm 0.1$ \\
\hline Moisture $(\%)$ & $10.2 \pm 0.07$ & $10.7 \pm 0.2$ & $10.0 \pm 0.1$ & $6.7 \pm 0.4$ \\
\hline Carbohydrate $(\%)$ & 64.15 & 64.67 & 65.09 & 68.14 \\
\hline \multicolumn{5}{|c|}{ Mean \pm standard deviation of three determinations; values } \\
\hline \multicolumn{5}{|c|}{ expressed on wet basis. } \\
\hline$b_{\mathrm{N}} \times 6.25$ & & & & \\
\hline${ }^{c}$ calculated by th & differenc & & & \\
\hline
\end{tabular}


Table 2. Effect of Extrusion Temperature on Water Absorption Capacity (WAC) of Full Fat Pinto Bean Flour at Various pH Levels Expressed as gms of Water/gm of Sample

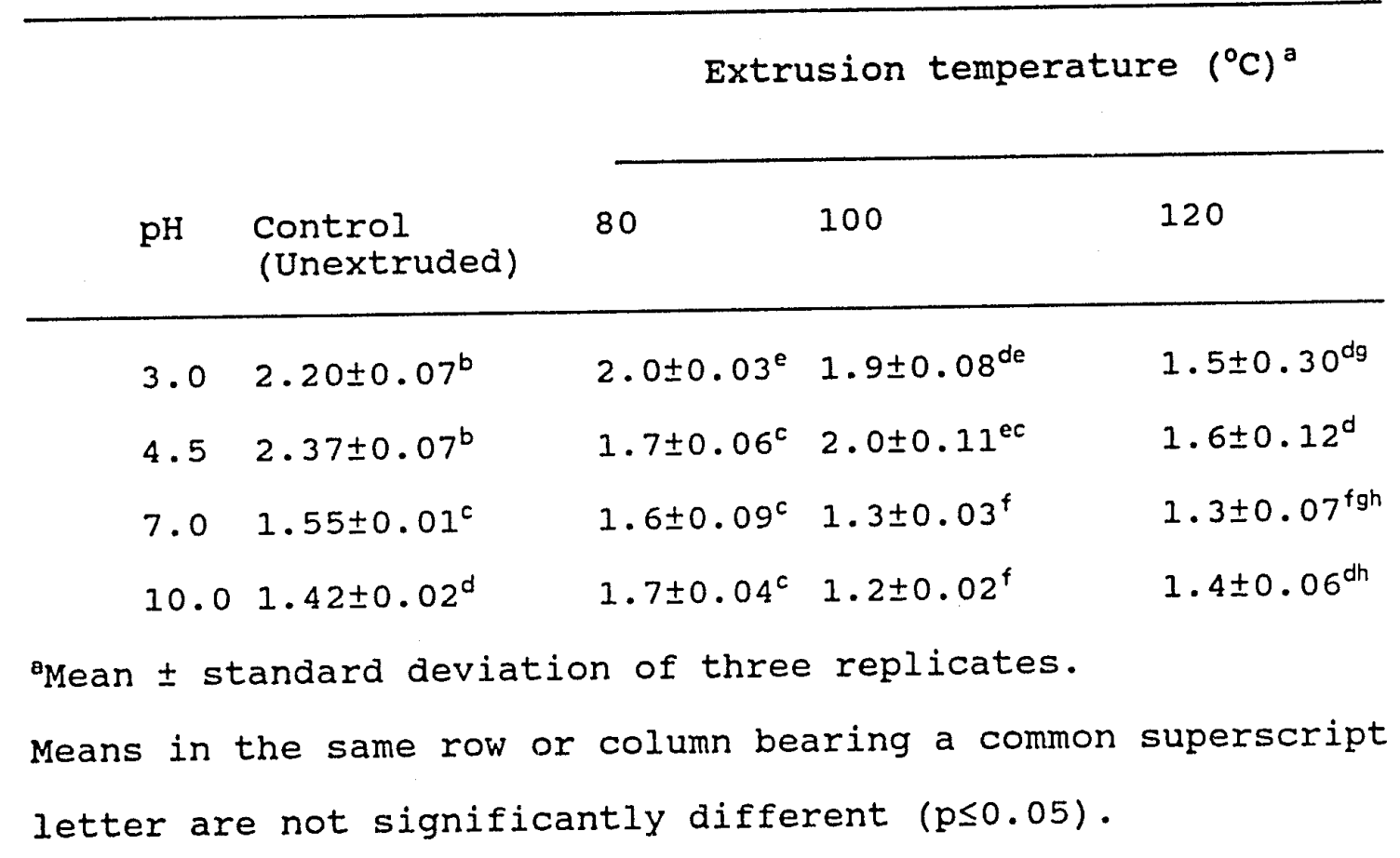


Table 3. Effect of Extrusion Temperature on Emulsification Capacity (EC) in Full Fat Pinto Bean Flour at Various $\mathrm{pH}$ Levels Expressed as ml of Corn oil/gm of Flour

$$
\text { Extrusion Temperature }\left({ }^{\circ} \mathrm{C}\right)^{a}
$$

\begin{tabular}{|c|c|c|c|}
\hline $\mathrm{pH}$ & $\begin{array}{l}\text { Control } \\
\text { (Unextruded) }\end{array}$ & 80 & 100 \\
\hline
\end{tabular}

$\begin{array}{lllll}3.0 & 176 \pm 5.3^{b} & 203 \pm 5.8^{c} & 49.3 \pm 1.1^{\mathrm{e}} & 19.3 \pm 1.1^{\mathrm{d}} \\ 4.5 & 177 \pm 2.5^{\mathrm{b}} & 223 \pm 6.8^{\mathrm{c}} & 29.3 \pm 1.1^{\mathrm{f}} & 31.6 \pm 2.9^{f} \\ 7.0 & 205 \pm 5.0^{\text {be }} & 259 \pm 1.1^{f} & 58.3 \pm 2.8^{\mathrm{d}} & 174 \pm 10.4^{\mathrm{g}} \\ 10.0 & 218 \pm 6.0^{\mathrm{ce}} & 253 \pm 5.7^{f} & 210 \pm 5.0^{\mathrm{c}} & 216 \pm 5.7^{\mathrm{c}}\end{array}$

Mean \pm standard deviation of three replicates.

Means in the same row or columns bearing a common superscript letter are not significantly different $(p \leq 0.05)$. 
Table 4. Effect of Extrusion Temperature on Hunter Color Values in Full Fat Pinto Bean Flours

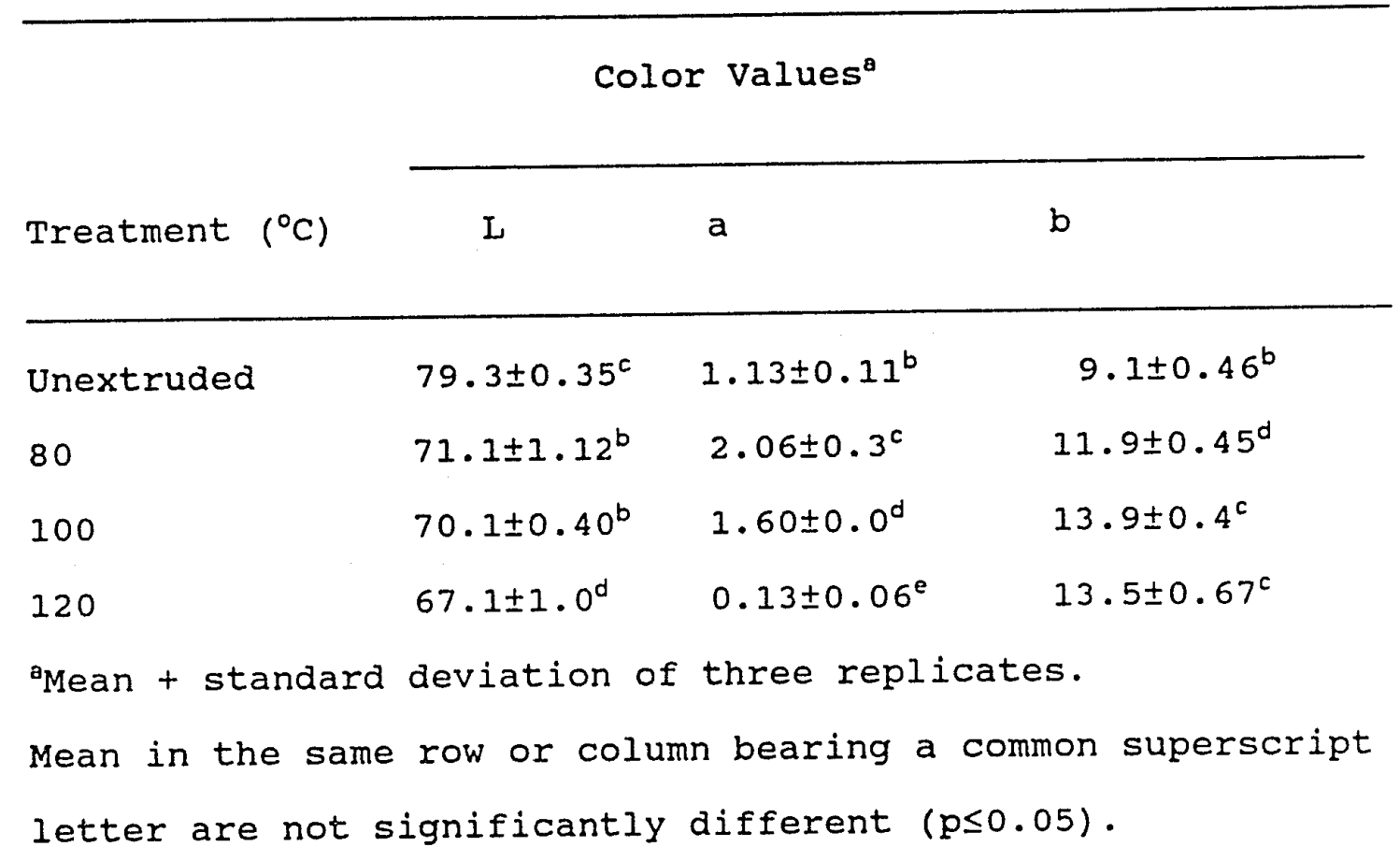




\section{Iiterature Cited}

AOAC. Official Methods of Analysis, 14th.; Association of Official Analytical Chemists: Arlington, VA 1984.

Abdelmonem, A. S.; Banasik, O.J.;\& Merlin, B.D. Protein isolates from navy and pinto beans: Their uses in Macaroni products. J.Agric. Food Chem, 1983, 31, 499502 .

Aguilera, J.M.; Crissafulli, B.E.; Lusas, E.W.; Uebersax \& Zabik, M. E. Air classification and extrusion of navy bean fractions. J.Food Sci. 1984, 49, 543-546.

Beuchat, I.R. Functional and electrophoretic characteristics of succinylated peanut flour proteins. J. Agric. Food Chem. 1977, 25, 258-260.

Collonna, P.; Tayeb, M.; and Mercier, C. (1989). Extrusion cooking of Starch and Starchy Products. Page 247 in: Extrusion Cooking. C. Mercier, P, Linko and J.M.Harper (Eds.) American Association of Cereal Chemists st. Paul Minnesota.

Guzka, E.; \& Khan, K. Effect of temperature on the properties of the extrudates from high starch fractions from navy,pinto, \& garbanzo beans. J. Food Sci. 1990, $\underline{55}, 466-469$.

Guzka, E.; Khan,K. High temperature short time extrusion effects on protein solubility and distribution in navy 
and pinto beans. J. Food Sci. 1991, 56, 1013-1016.

Hermannson, A.M. Methods of studying functional

characteristics of vegetable proteins.J. Am. Oil Chem. Soci. 1979, 56, 242-246.

Hutton, C.W.; Campbell,A.M. Functional properties of a soy concentrate and a soy isolate in simple systems.J. Food Sci. $1977, \underline{42}, 454-456$.

Ishino, $\mathrm{K} \&$ okamoto, S. Molecular interaction in alkali denatured soybean proteins. Cereal Chem. 1975, 52, 921.

Kinsella, J.E. Functional properties of soy proteins.J. Am. 이 chem. Soci. 1979, 56, 242-258.

Lee, J.P.; Uebersax, M.A.; Zabik, M.E.; Hosfeild, G.L.; \& Lusas, E.W. Physicochemical characteristics of dry roasted navy bean flour fractions. J. Food Sci. 1983, 48, $1860-1875$.

Maga, J.A.; \& Sizer, C.E. The fate of free amino acids during the extrusion of potato flakes. Leben-WissenTech, 1979, 12, 13-14.

Maga,J.A.,\& Cohen,H.R. Effect of extrusion parameters on certain physical, sensory and nutritional properties of potato flakes. Lebens-Wissen-Technol, 1978, 11, 195197.

Mcwatters, K.H.; \& Holmes, M.R. Influence of moist heat on solubility and emulsification properties of soy and 
peanut flours.J. Food Sci. 1979, 44, 774-776.

Morr, C. V.; German, B.; Kinsella, J.E.; Regenstein, J. M.; Van Buren, J.P.; Kilara, A.; Lewis, B.A. \& Mangino,

M.E. A Collaborative study to develop a standardized food protein solubility procedure. J. Food Sci, 1985, 50, 1715-1718.

Narayana, K.; Narsingarao Rao, M.S Functional Properties of raw and heat processed winged bean (Psophocarpus tetragonolobus) flour. J. Food Sci. 1982, 47, 15341538 .

Noguchi, A.; and Cheftel, J.C. Extrusion cooking of protein enriched cookies. Nipp. Shoku. Kogyo Gakk. $1983,2,114-124$.

Pham, C.B.; \& Rosario, R.R. Studies on the development of texturized vegetable products by extrusion process. I. Effect of processing variables on protein properties. J. Food Technol. 1984, 19, 535-547.

Pilosof, A.M.; Bartholomai, G.B.; \& Chirife, J. Kinetics of nitrogen solubility loss in heated flour and protein isolates from bean, Phaseolus vulgaris. J. Food Sci. $1981, \underline{47}, 4-7$.

Sathe, S. K.; Deshpande, S. S.; \& Salunke, D. K. Functional properties of lupin seeds (Lupinus metabilis) proteins and protein concentrates. J. Food Sci. 1982, 47, 491497 . 
Sathe, S.; Deshpande, S.S.; \& Salunke, D.K. French Beans. In Salunke \& Kadam (Ed). CRC handbook of world food legumes. 1989. (pp-23-63). CRC press Boca Raton Florida.

stanley, D.W. Protein reactions during extrusion processing. In Mercier,C (Ed.). Extrusion Cooking.1989. (pp.321-341). st. Paul Minnesota: American Association of Cereal Chemists.

Shagun, J.F.; \& Harper, J.M. Effect of screwrestrictions on the performance of an autogenous extruder. J. Food Process Engg. 1980, 3, 199-216. 


\section{Chapter 3}

\section{SUMMARY AND RECOMMENDATIONS}

summary

Full fat flour prepared from whole pinto beans was made into a dough with $40 \%$ moisture and extruded in a single screw extruder. Extrusion was carried out at 80,100 and $120^{\circ} \mathrm{C}$. Resulting extrudates were dried at $45^{\circ} \mathrm{C}$ and ground to pass a 40 mesh sieve. Ground extrudates were analyzed for proximate composition (crude protein, crude fat, ash, moisture, and total carbohydrates) color, and functional properties (nitrogen solubility, water absorption capacity, and emulsification capacity) and compared against the unextruded full fat flour. Nitrogen solubility, water absorption capacity and emulsification capacity were determined at $\mathrm{pH} 3,0,4.5,7.0$ and 10.0 . The results of the proximate analysis showed that protein level was $23.5 \%$ and the fat content of the flour extrudates were low (1.2\%). The moisture level decreased from $10 \%$ at control to $6.7 \%$ at $120^{\circ} \mathrm{C}$. The total carbohydrate (obtained by the difference method) and mineral ( $\%$ ash) contents of the unextruded and the extruded samples were the same.

The nitrogen solubility of the unextruded flours showed a typical nitrogen solubility-pH profile. Nitrogen solubility decreased slightly from $\mathrm{pH} 3.0$ to 4.5 , and 
increased significantly thereafter upto $\mathrm{pH}$ 10.0. Extrudates obtained at 80,100 and $120^{\circ} \mathrm{C}$ on the other hand showed a slightly different profile and the extent of nitrogen solubility change appeared to be dependent on the extrusion temperature, and at a given temperature the solubility of increased as the $\mathrm{pH}$ of the extracting medium increased. While no significant difference was observed in the protein content of the unextruded and the extruded pinto bean flour, a significant $(p \leq 0.05)$ decrease in the nitrogen solubility was observed at 80 and $100^{\circ} \mathrm{C}$. While the nitrogen insolubilization effect at 80 and $100^{\circ} \mathrm{C}$ was obvious a different trend was observed in the extrudates at $120^{\circ} \mathrm{C}$. A higher nitrogen solubility was observed at pH 7.0 , compared to the control, but no significant difference ( $p \leq 0.05)$ was observed at $\mathrm{pH} 3.0$ and 4.5. A significantly lower nitrogen solubility was observed at $\mathrm{pH} 10.0$ compared to the control. Maga \& Sizer (1979) found increased levels of amino acids at 100 and $130^{\circ} \mathrm{C}$ in comparison to the ones treated at $70^{\circ} \mathrm{C}$ in potato flakes. They attributed the increase in amino acid levels to protein hydrolysis.

The water absorption capacity of the control and the extrudates are $\mathrm{pH}$ dependent and the extent of change due to extrusion appeared to be temperature dependent. In general the WAC decreased with the increase in pH. Extrudates at 80 and $100^{\circ} \mathrm{C}$ showed reduced WAC, and the WAC was lower than the 
control at all $\mathrm{pH}$ levels except at $\mathrm{pH} 7.0$ when treated at $80^{\circ} \mathrm{C}$. The extrusion at $120^{\circ} \mathrm{C}$ further decreased the WAC compared to the control at all $\mathrm{pH}$ levels though it was not significantly different $(p \leq 0.05)$ compared to $100^{\circ} \mathrm{C}$ at $\mathrm{pH} 3.0$ and 4.5 .

The emulsification capacity of the extrudates was high at all $\mathrm{pH}$ levels at $80^{\circ} \mathrm{C}$ compared to the control. The EC-pH relationship seemed to follow a similar pattern to the solubility-pH relationship where the EC increased with the increasing $\mathrm{pH}$. The EC seemed to have increased slightly compared to the control and then significantly decreased $(p \leq 0.05)$ at $100{ }^{\circ} \mathrm{C}$. Extrusion at $120^{\circ} \mathrm{C}$ further decreased the EC compared to the control although no change in the EC was observed at $\mathrm{pH}$ 10.0. Hunter color values obtained showed a decrease in " $L$ " value as expected and the "b" value increased indicating an increase in the yellow color of the flour with an increase in the temperature. The "a" value decreased fron 80 to $100^{\circ} \mathrm{C}$ then changed into a negative value indicating an appearnce of green color at $120^{\circ} \mathrm{C}$. Noguchi and Cheftel (1983) suggested that the browning occured due to the nonenzymatic browning at high temperature and low moisture content.

\section{RECOMMENDATIONS}

Further research needs to be performed on the optimization of conditions like temperatures higher than 
$120^{\circ} \mathrm{C}$, moisture conditions higher and lower than $40 \%$, and screw speed more than $75 \mathrm{rpm}$, to obtain an effect on quality of the ingredient, which could be used in a wide variety of the food systems.

To utilize the extruded pinto bean flour as an ingredient, further research needs to be conducted to determine other functional properties such as foaming, viscosity, gelation, cohesion-adhesion, elasticity, fat absorption capacity, flavor binding, etc., of the full fat flour for its use in diversified food products.

Studies should be performed on certain other factors that effect solubility other than $\mathrm{pH}$ such as ionic strength, salt concentration etc. Of the $\mathrm{pH}$ levels used in this study a $\mathrm{pH}$ of 10.0 is not a practical $\mathrm{pH}$ for most food systems; therefore it is suggested that a pH range of 4.0 and 8.0 should be studied where practically most of the food systems exists.

Increased nitrogen solubility at $120^{\circ} \mathrm{C}$ suggests that protein hydrolysis takes place at higher temperatures, which in turn affects the functional property. Studies at temperatures higher than $120^{\circ} \mathrm{C}$ should be performed to investigate the changes that occur in functionality, especially solubility.

The effect of extrusion temperature on the antinutritional factors (Trypsin inhibitors, phytates, 
polyphenols etc.) and its effects on pinto bean protein digestibility will help us in the goal of increased utilization of pinto beans as an ingredient. Further testing of this product should be conducted for consumer acceptability as an ingredient and its feasibility and economics compared to the products aiready in the market such as steamed beans, full fat ground flour etc. for full utilization in food systems. 


\section{REFERENCES}

AOAC. Official Methods of Analysis, 13th ed. Association of official Analytical Chemists: Washington, DC, 1984. Abdelmonem, A.S., Banasik, O.J., \& Merlin,B.D. (1983) • Protein isolates from navy and pinto beans: Their uses in macroni products. Journal of Agricultural and Food Chemistry, 31, 499-502.

Aguilera, J.M., Crissafulli, B.E., Lusas, E.W., Ubersax \& Zabik, M.E.(1984). Air classification and extrusion of navy bean fractions. Journal of Food Science, 49, 543546 .

Beuchat, L.R. (1977). Functional and electrophoretic characteristics of succinylated peanut flour proteins. Journal of Agriculture and Food Chemistry, 25, 258260 .

Cheftel, J. C., Chq,J.L and Lorient, D (1985). Amino acids, peptides and proteins. Pages 245-369 in Food Chemistry 2nd ed.o. R. Fennema ed Marcel Dekker Inc. New York. Collona, P., Tayeb, M., and Mercier, C. (1989). Extrusion cooking of starch and starchy products. Page 247 in: Extrusion Cooking. C. Mercier, P, Linko and J.M. Harper (Eds.) American Association of Cereal Chemists st. Paul Minnesota.

Crenweldge, D.D., Dill, C. W., Tybor, P. T., Landman, 
W.A. (1974). A comparison of the emulsification capacities of some protein concentrates. Journal of Food Science, 39, 175-177.

Frazen, K.L and Kinsella, J.E. (1976). Functional properties of succinylated and acetylated soy proteins. Journal of Agricultural and Food Chemistry, 24, 788-794.

Guzka, E., \& Khan,K.(1990). Effect of temperature on properties of extrudates from high starch fractions from navy, pinto, \& garbanzo beans. Journal of Food Science, 55, 466-469.

Guzka,E.,\& Khan,K. (1991). High temperature short time extrusion effects on protein solubility and distribution in navy and pinto beans. Journal of Food Science, 56, 1013-1016. Harper, J.M. (1979). Extrusion of foods. CRC Critical Review in Food Science and Nutrition, 11, 155-215. Hauck, B.W \& Huber, G.R.(1989). Single screw Vs twin screw Extrusion, Cereal Foods World, 34, 930-939.

Hermannson. A.M. (1979). Methods of studying functional characteristics of vegetable proteins. Journal of American oil Chemists Society. 56, 242-246. Hutton,C.W., Campbell,A.M.(1977). Functional properties of a soy concentrate and soy isolate in simple systems. Journal of Food Science. $42,454-456$. 
Ishino, K \& Okamato, S. (1975). Molecular interactions in alkali denatured soy bean proteins. Cereal Chemistry. 52, 9-21.

Jeunink, J. and Cheftel, J.C. (1979). Chemical and physiochemical changes in field bean and soy bean proteins texturized by extrusion. Journal of Food Science, $\underline{44}, 1322-1328$.

Johnson, D.W.(1970). Functional properties of oil seeds proteins. Journal of American $0 i 1$ seeds proteins.47, 402-405.

Kinsella J.E (1976). Functional properties of Proteins in foods: A survey. CRC Cxitical Reviews of Nutrition and Food Science, I, 219- 280 .

Kinsella, J.E.(1979). Functional properties of soy proteins. Journal of American Oil Chemists, 56, 242258 .

Kon, S., Wagner, J.R., and Booth,A.N. (1977). Legume powders. Preparation and some antinutritional and physicochemical properties, Journal of Food Science, 39, 897.

Labuza, T.P.,Warren, R.M.and Warmbier, H.C.(1977). The physical aspects with respect to water and non enzymatic protein browning. Pages 379-418 in protein crosslinking, Nutritional and Medical consequences. $M$. Friedman, ed. Plenum press, New York. Lavitt, R.D., Felsted,R.D and Bachur, N.R (1977). Biological 
and biochemical properties of Phaseolus vulgaris isolectins, Journal of Biological Chemistry, 252, 29612965.

Lee, J.P., Ubersax, M.A., Zabik., Hosfeild, G.L., \& Lusas, E.W. (1983) . Physicochemical characteristics of dry roasted navy bean fractions. Journal of Food Science. 48, 1860-1875.

Linko, P. (1983). Recent progress in the art of extrusion cooking. Progress in Food Engineering, c. Cantarelli \& c. Peri, eds. Forster Publishing Ltd., Kushacht Switzerland. 593-609.

Lin, M.J.Y., Humbert, E.S. \& Soluski, F.W.(1974). Certain Functional properties of sunflower meal products. Journal of Food Science, 39, 368-370.

Maga, J.A., \& Sizer, C.E. (1979). The fate of free amino acias during extrusion of potato flakes. LebensmittelWissenchaftund-Technologie, 12, 13-14.

Maga, J.A.\& Cohen, H.R. (1978). Effect of extrusion parameters on certain physical, sensory and nutritional properties of potato flakes. LebensmittelWissenchaftund-Technologie. 11,195-197.

Mattil, K. F. (1971). The functional requirements of protein for foods. Journal of oil Chemists Society, 48, 447449 .

Mercier, C.(1977). Effect of Extrusion Cooking on potato 
starch using a twin screw french extruder. Staerke, $\underline{28}(2): 48-52$.

Millerd, A. (1975) . Biochemistry of legume seed proteins, Annual Review of Plant Physiology. 26, 53-72.

Molina, M.R. Fuente,G. de Ia., and Bressani, R. (1975) Interrelationships between storage, soaking time cooking time, nutritive value and other characteristics of black beans (Phaseolus vulgaris). Journal of food Science, $40,587-591$.

Morr, C.V., German,B., Kinsella, J.E., Regenstein, J.M., Van Buren, J.P., Kilara, A., Lewis, B.A. \& Mangino, M.E.(1985). A Collaborative study to develop a standardized food protein solubility procedure. Journal of Food Science, 50, 1715-1718.

Narayana, K., Narsingarao, M.S.(1982). Functional properties of raw and heat processed winged bean (Psophocarpus tetragonolobus) flour. Journal of Food Science, 47 , 1534-1538.

Noguchi, A., and Cheftel, J.C. (1983). Extrusion cooking of protein enriched cookies. Nippon Shokuhin Kogyo. $\underline{2}$, 114-124.

Pham, C. B., \& Rosario, R.R. (1984). Studies of the development of texturized vegetable products by extrusion process. I. Effect of processing variables on protein properties. Journal of Food Technology. 19, 
535-547.

Pilosof. A.M., Bartholomai, G.B., \& Chirife, J. (1981).

Kinetics of nitrogen solubility loss in heated flours

and protein isolates from bean, Phaseolus vulgaris. Journal of Food Science, 47, 4-7.

Rakosky, J.(1987). Soy grits, flour, concentrates and isolates in meat products. Journal of American oil Chemists Society, 51, 123-126.

Rhee,K.C.,Kuo, C.M and Lusas, E.W.(1981). Texturization, Pages 51-88 in: Protein Functionality of Foods. J.P.Cherry, ed. Am.Chem.Soc., washington D.C.

Sathe, S.K., Deshpande,S.S., Salunke,D.K.(1982). Functional Properties of Lupin seed (Lupinus mirabilis) Protein and protein concentrates, Journal of Food Science, 47 , 491-497.

Sathe, S. K and Salunke, D.K.(1981). Functional properties of great northern bean (Phaseolus vulgaris $L$ ) protein emulsion, foaming, viscosity and gelation properties. Journal of Food Science, 46, 71-74.

Sheard, P.R.,Ledward, D.A. and Mitchell, J.R. (1985). Comparison of the extrusion cooking of soy isolate and a soya flour Journal of Food Technology, 20,763-771. Soluski, F., Humbert, E.S., Bui, K and Jones, J.D. (1976) . Functional properties of rapeseed flours, concentrates and isolates. Journal of Food Science. 41, 1349-1352. 
Stanley, D.W. (1989). Protein reactions during extrusion processing. In Mercier, C (Ed.). Extrusion Cooking (pp. 321-341). St. Paul Minnesota: American Association of Cereal Chemists.

Shagun, J.F., \& Harper, J.M.(1980). Effect of screw restrictions on the performance of an autogenous extruder. Journal of Food Process Engineering, 3, 199216.

Thompson, L.U.(1977). Preparation and evaluation of mung bean protein isolates. Journal of Food Science, 42,202206.

West,S.I.(1984). Food Proteins: sources and properties, Journal of Chemical Technology and Biotechnology, 34 , $176-181$. 